\title{
Intellectual Capital and Its Impact on the Financial Performance of Russian Manufacturing Companies
}

\author{
Tatiana Andreeva ${ }^{a}$ \\ Lecturer, School of Business, tatiana.andreeva@nuim.ie. \\ Tatiana Garanina ${ }^{b}$ \\ Associate Professor, Graduate School of Management, garanina@gsom.pu.ru. \\ ${ }^{a}$ Maynooth University, Maynooth, Co. Kildare, Ireland.

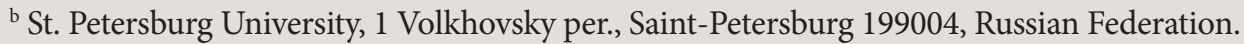

\begin{abstract}
$\mathrm{I}$ $\mathrm{t}$ has been argued that intellectual capital (IC) is the key element of value creation in the contemporary economy. According to expert calculations, in the 1980s the share of tangible assets accounted for about $62 \%$ of market capitalization of companies on developed markets. However, by the start of the 2000 s, their share fell to $16 \%$. This has been widely supported by empirical research, but mainly based on the data from developed markets. The questions as to how IC and its elements work on emerging markets remains under-researched due to a lack of empirical research devoted to this topic. The aim of the study is to provide empirical insight into the relationship between three main elements of IC (human, relational and structural) and the organisational performance of Russian companies, such as asset profitability, net sales growth and market share. The sample includes 240 Russian companies. Information about different elements of intellectual capital has been gathered with the help of a questionnaire that has been answered by the executive management of the companies included in the sample over the course of January-March 2015. The data was collected with a survey using the scales that have

already been applied internationally. The findings based on regression analysis demonstrate that structural and human capital positively influence organisational performance, while relational capital does not.

We can assume that the results we obtained can be explained by the specific features of the analysed industries. For manufacturing companies, organisational structure and the effectiveness of internal processes play a much more important role in company value creation than relationships with customers and other stakeholders. The core managerial implication of this study is that building structural capital, providing employees with efficient and relevant information systems and tools to support cooperation between employees, as well as carefully documenting organisational knowledge and making it easily accessible for employees, should be in the focus of the managers of manufacturing companies. The concept of IC management in our article was developed within the international context and focuses on emerging markets. At the end of the paper, the main areas for further research are presented.
\end{abstract}

\section{Keywords:}

intellectual capital;

elements of intellectual capital;

companies' performance;

manufacturing sector;

Russia.
Citation: Andreeva T., Garanina T. (2017) Intellectual Capital and Its Impact on the Financial Performance of Russian Manufacturing Companies. Foresight and STI

Governance, vol. 11, no 1, pp. 31-40. DOI: 10.17323/2500-2597.2017.1.31.40. 
$\mathrm{K}$ nowledge-based assets are turning into a key factor affecting companies' growth in the presentday economy. In the long term, companies that innovate on a regular basis, which make full use of new knowledge and technologies, skills and experience of their staff, and which have put an adequate organisational infrastructure into place, tend to become successful and competitive. Added value created by companies is increasingly generated from intangible assets [Edvinsson, Malone, 1997; Guthrie, 2001; Sveiby, 1997]. The latter include knowledge, know-how, innovation potential, licence agreements, management culture, and other resources of company growth. The firm's ability to manage such assets is crucial for its prospects in the knowledge-based economy. However, relevance of these concepts, which are well established in the international literature, still needs to be verified for the Russian market.

Limitations hindering the direct application of international management theories in Russia were analysed in a number of Russian studies (e.g. [Elenkov, 1998; Andreeva, 2008]). Other researchers concentrated on the specific cultural and institutional context, as a part of which knowledge-based processes take place in a different way compared with Western or Japanese companies [Andreeva, Ikhilchik, 2009; May, Stewart, 2013]. However, despite these efforts, the question of how applicable the concept of intellectual capital is to Russian realities remains open. Very few studies have researched the relevant issues on the basis of Russian material [Baiburina, Golovko, 2008; Bykova, Molodchik, 2011; Volkov, Garanina, 2007; Garanina, 2010; Tomchuk et al., 2013], and their results frequently were quite different from international ones. For example, tangible assets make a much more substantial contribution to Russian companies' performance than intellectual capital does; note that studies of other emerging markets produced similar results [Chan, 2009; Suraj, Bontis, 2012; etc.]. On the contrary, on developed markets, intellectual capital plays a key role in companies' performance [Inkinen, 2015; Molnar, 2004].

The specific correlation between key intellectual capital elements and Russian companies' performance indicators remains insufficiently researched due to several reasons. Firstly, the existing studies use small samples, typically consisting of just over 100 companies [Bykova, Molodchik, 2011], which makes the authors' conclusions significantly less representative and valid. Secondly, some of the indirect indicators applied to assess intellectual capital elements were severely criticised in international literature as poorly reflecting the actual state of affairs at the companies [Coombs, Bierly, 2006]. However, on the whole Russian studies note a positive correlation between corporate performance indicators and intellectual capital [Bykova, Molodchik, 2011; Volkov, Garanina, 2007; Garanina, 2010], the characteristics of the latter's specific elements frequently turn out to be incompatible, due to essential incongruity of analytical tools applied by the authors.

Increasing Russian businesses' competitiveness requires an understanding of the workings of intellectual capital management mechanisms [Dumay, Garanina, 2013]. This, in turn, means that Russian companies must know which intellectual capital elements directly affect their performance indicators. The paper strives to answer the following questions:

- Is there a connection between intellectual capital and Russian companies' performance?

- Which intellectual capital elements have the strongest impact on Russian companies' performance indicators?

240 manufacturing companies operating in various Russian regions were included in the sample. A survey of their managers provided data on various intellectual capital elements; the study contributes to the further development of the relevant concept. The results of the study may promote Russian companies' competitiveness, by helping them to better understand the role of intellectual capital and ways to efficiently manage it in the Russian institutional and cultural context (see, e.g., [May, Stewart, 2013]).

The first section of the paper introduces the basic concepts and reviews other studies of the correlation between various intellectual capital elements and companies' performance. Next, the methodology, sample, and conclusions are presented, arrived at by applying models based on structural equations. In the concluding section, recommendations on managing intellectual capital elements are provided and areas for future studies are outlined.

\section{Elements of intellectual capital and companies' performance}

In line with the dynamic approach presented earlier in [Volkov, Garanina, 2007, p. 87], we understand intellectual capital as "the company's ability to turn its current resources, skills, and competencies into future economic benefits". This definition implies that achieving growth requires not just an understanding of the nature of intellectual capital, but also the possession of special competencies required to efficiently apply it to obtain economic benefits in the future. There ifs no consensus among scholars regarding the structure of intellectual capital [Molodchik et al., 2014], but the majority [Edvinsson, Malone, 1997; Sveiby, 1997] are inclined to distinguish three key elements: human, relational, and organisational (or structural) capital. 
We define human capital as a company's ability to economically benefit from the potential of their staff, embodied in the latter's knowledge, skills, experience, innovativeness, creativity, loyalty, efficiency, ability to learn, motivation to develop, etc. Similarly, relational capital is seen not as a resource but as a company's ability to make use of the potential offered by its internal and external interactions [Volkov, Garanina, 2007] - i.e. good relations with clients, suppliers, partners, and other parties. Organisational (structural) capital, sometimes referred to as the company's "skeleton" or "glue" holding it together, amounts to the management's ability to efficiently apply such intangible assets as corporate culture, philosophy and mission, management structure, and efficient business processes, including those related to the accumulation and transfer of knowledge.

The correlation between companies' performance and various elements of their intellectual capital has been thoroughly studied in developed countries [Bontis, 1998; Cabello-Medina et al., 2011; Maditinos et al., 2011; Mention, Bontis, 2013; Subramaniam, Youndt, 2005]. Numerous international authors recognise the decisive role of human capital in improving companies' financial performance [CabelloMedina et al., 2011; Jardon, Martos, 2012; Mention, Bontis, 2013], and in increasing their structural and relational capital. This is due to the fact that educated, skilled, and experienced staff tend to establish better relationships with a wide range of partners (thus capitalising on relational assets), and improve the efficiency of business processes (thus generating structural capital) [Cabrita, Bontis, 2008; Kim et al., 2012]. Other authors, on the contrary, insist that relational capital ultimately makes the highest contribution to companies' financial performance [Reed et al., 2006; Huang, Hsueh, 2007; Sharabati et al., 2010]: reliable client and supplier relations allow for cutting costs and increasing sales, thus improving the company's overall competitiveness.

Henri Inkinen [Inkinen, 2015] presented a thorough review of empirical studies on the role of human capital comprising more than fifty relevant works. He said companies' performance is most often measured using internal (or accounting) indicators such as returns on assets and equity, sales dynamics, innovation activity, and certain external (or market) indicators measuring the company's capitalisation, Tobin's coefficient, or market share. Inkinen concludes that intellectual capital first of all positively affects companies' innovation activity, while its various elements create a synergy which increases their combined impact on the firm's performance [Inkinen, 2015].

The question of the forms the above correlation takes in Russia remains open. We tried to summarise the results of previously conducted studies on correlation between various intellectual capital elements and Russian companies' performance in Table 1. The only issue about which Russian researchers seem to agree is the positive effect of structural capital on corporate performance, which contradicts the evidence from developed countries where human capital plays the key role [Inkinen, 2015]. The view of the other two intellectual capital elements varies significantly. Not all researchers even consider relational capital at all, so we were unable to assess its importance. The different opinions of Russian researchers may be explained by the fact that they have studied different industries during different periods of time, using different tools individually selected for each specific case. Also, most of the reviewed studies were based on small samples - which limits the applicability of the authors' conclusions.

The authors of the reviewed studies used only open data sources and did not have access to raw data. In our opinion, the potential effect of intellectual capital elements on companies' financial performance should primarily be studied in an empirical manner, among other things through the prism of company managers' opinions. This approach turns out to be much more productive in terms of increased the efficiency of companies' operations.

Taking into account the controversial conclusions about intellectual capital elements' correlation with Russian companies' performance indicators suggested by the authors of previously conducted studies, we propose the following preliminary hypotheses:

H1: There is a positive correlation between human capital and companies' performance indicators.

H2: There is a positive correlation between relational capital and companies' performance indicators.

H3: There is a positive correlation between structural capital and companies' performance indicators.

\section{Methodology of the study \\ Sample and data collection procedures}

The range of companies surveyed during our study was limited to those employing at least 100 people, which use sufficiently formalised management practices. The issues under consideration can be researched for various sectors of the economy, though the service companies, which on average tend to be relatively small, do not allow for building a representative sample meeting the minimum number of employees mentioned above. Their inclusion in the sample along with manufacturing companies would result in 
Table 1. Results of empirical studies of the correlation between Russian companies' intellectual capital and their performance

\begin{tabular}{|c|c|c|c|c|c|c|c|}
\hline \multirow[t]{2}{*}{ Authors } & \multirow[t]{2}{*}{$\begin{array}{l}\text { Country, industry, } \\
\text { sample size }\end{array}$} & \multirow{2}{*}{$\begin{array}{c}\text { Intellectual } \\
\text { capital } \\
\text { measurement } \\
\text { technique }\end{array}$} & \multirow[t]{2}{*}{$\begin{array}{c}\text { Companies' performance } \\
\text { indicators }\end{array}$} & \multicolumn{3}{|c|}{$\begin{array}{l}\text { Impact of intellectual } \\
\text { capital elements }\end{array}$} & \multirow[t]{2}{*}{ Note } \\
\hline & & & & $\mathrm{HC}$ & RC & SC & \\
\hline $\begin{array}{l}\text { [Tovstiga, } \\
\text { Tulugurova, } \\
\text { 2007] }\end{array}$ & $\begin{array}{l}\text { Russia, } 20 \\
\text { innovative } \\
\text { companies in St. } \\
\text { Petersburg and } \\
\text { Leningrad Region }\end{array}$ & Survey & $\begin{array}{l}\text { Internal (accounting) } \\
\text { and external (market) } \\
\text { performance indicators }\end{array}$ & + & $\mathrm{n} / \mathrm{a}$ & + & \\
\hline $\begin{array}{l}{[\text { Bayburina, }} \\
\text { Golovko, 2008] }\end{array}$ & $\begin{array}{l}\text { Russia, } 19 \\
\text { companies } \\
\text { specialising in } \\
\text { various industries }\end{array}$ & Proxy indicators & IP added value & + & $\mathrm{n} / \mathrm{a}$ & + & $\begin{array}{l}\text { A positive impact } \\
\text { of innovation and } \\
\text { network capital was } \\
\text { also established }\end{array}$ \\
\hline $\begin{array}{l}\text { [Garanina, } \\
2010]\end{array}$ & $\begin{array}{l}\text { Russia, } 43 \\
\text { companies; } \\
\text { industry not } \\
\text { specified }\end{array}$ & Proxy indicators & Share price & ++ & $+/$ no & + & $\begin{array}{l}\text { Results somewhat } \\
\text { varied between } \\
\text { industries. Relational } \\
\text { capital had the } \\
\text { highest impact on } \\
\text { telecommunication } \\
\text { companies, while in } \\
\text { the energy industry it } \\
\text { was insignificant }\end{array}$ \\
\hline $\begin{array}{l}\text { [Bykova, } \\
\text { Molodchik, } \\
\text { 2011] }\end{array}$ & $\begin{array}{l}\text { Russia, the } \\
\text { Perm Region, } \\
115 \text { companies; } \\
\text { industry not } \\
\text { specified }\end{array}$ & VAIC & $\begin{array}{l}\text { Returns on equity, sales } \\
\text { dynamics }\end{array}$ & + & $\mathrm{n} / \mathrm{a}$ & + & $\begin{array}{l}\text { A positive correlation } \\
\text { was found only } \\
\text { with the dependent } \\
\text { variable measuring } \\
\text { rate of sales }\end{array}$ \\
\hline $\begin{array}{l}\text { [Molodchik, } \\
\text { Nursubina, } \\
\text { 2012] }\end{array}$ & $\begin{array}{l}\text { USA ( } 143 \\
\text { companies), Russia } \\
\text { (60 companies); } \\
\text { industry not } \\
\text { specified }\end{array}$ & Proxy indicators & $\begin{array}{l}\text { Share of new products } \\
\text { in the product range } \\
\text { (innovation activity) }\end{array}$ & - & + & + & $\begin{array}{l}\text { Explanatory power of } \\
\text { the model was higher } \\
\text { when Russian data } \\
\text { was used (compared } \\
\text { with the US data) }\end{array}$ \\
\hline $\begin{array}{l}\text { [Tomchuk et } \\
\text { al., 2013] }\end{array}$ & $\begin{array}{l}\text { Russia, the } \\
\text { Perm Region, } \\
15 \text { companies; } \\
\text { industry not } \\
\text { specified }\end{array}$ & VAIC & Profit margin & + & $\mathrm{n} / \mathrm{a}$ & + & \\
\hline \multicolumn{8}{|c|}{$\begin{array}{l}\text { "Legend: } \\
\mathrm{HC}=\text { human capital; } \mathrm{RC}=\text { relational capital; } \mathrm{SC}=\text { structural capital; } \\
++=\text { strong positive correlation, defined as one explanatory variable coefficient being significantly larger than others; }+=\text { positive correlation; - = negative } \\
\text { correlation; no = no correlation established; } \mathrm{n} / \mathrm{a}=\text { data not available because this intellectual capital element was not assessed. }\end{array}$} \\
\hline
\end{tabular}

a noticeable bias in favour of the latter. These industries have a different configuration of intellectual capital elements, and tend to use different approaches in managing them [Kianto et al., 2010], which creates additional problems with the comparative analysis of correlation with companies' performance.

Given the above limitations, we decided to concentrate on manufacturing companies in our study a strategic sector for the Russian economy whose traditionally important role is confirmed by official statistics: the manufacturing industry's contribution to the GDP in 2014 amounted to $32.4 \%^{1}$. The data for analysis was collected in the period of January-March, 2015; its representativeness and diversity were ensured by wide territorial (24 Russian regions) and industrial (11 manufacturing industries) coverage. Companies employing more than 100 workers were identified in the surveyed regions - 615 altogether, approximately evenly distributed between the various regions and industries. At the next stage, the members of the company contracted to provide support during the survey invited top managers (general directors, heads of personnel departments, or other executives of a similar position) to take part in a telephone interview. In the end managers from 240 companies were surveyed, or $39 \%$ of the total sample. The highest representation was achieved for the city of Moscow and the Moscow Region (12.5\%), Yekaterinburg and the Sverdlovsk Region (10\%), St. Petersburg and the Leningrad Region (8.8\%). Industry-wise, the largest shares of companies specialised in mechanical engineering (including the production of electrical machinery and equipment, $17.5 \%$ ), vehicle production (11.7\%), the food (10.4\%) and light (9.6\%) industries.

Most of the respondents hold important positions at their companies (Table 2). We believe their experience and authority were sufficient to objectively assess their companies' situation, management practices, and performance.

${ }^{1}$ Gross domestic product, annual data by OKVED sections // Federal Statistical Service. Available at: http://www.gks.ru/free_doc/ new_site/vvp/vvp-god/tab10.htm, last accessed on 9.01.2017 (in Russian). 
Table 2. Information about the survey respondents

\begin{tabular}{|l|r|r|}
\hline \multicolumn{1}{|c|}{ Position in the company } & Number of companies & Share in the sample, \% \\
\hline Deputy general director & 93 & 38.8 \\
\hline Other management positions & 58 & 24.2 \\
\hline Personnel director & 56 & 23.3 \\
\hline General director & 33 & 13.7 \\
\hline Source: compiled by the authors. & \multicolumn{2}{|l}{} \\
\hline
\end{tabular}

\section{Study tools}

The various elements of intellectual capital are assessed in different ways. Researchers usually adopt one of three major approaches. In the first case, they prepare practical, applied recommendations for company managers. For example, the Skandia Navigator [Edvinsson, Malone, 1997] or the Intangible Asset Monitor [Sveiby, 1997] techniques are based on algorithms for assessing intellectual capital which, due to the lack of a solid conceptual framework, cannot be standardised - and therefore only have limited applicability. For the same reason such methods are not suitable for quantitative studies which imply analysing large volumes of aggregated data on the companies included in the samples.

The second approach is based on assessing intellectual capital elements using various proxy indicators calculated on the basis of open source data. An example of using this approach is the Value Added Intellectual Coefficient (VAIC) model [Pulic, 2000]. The following indicators are used most often: labour costs to assess human capital [Sydler et al., 2013; Pulic, 2000]; administrative costs and R\&D expenditures to assess structural capital [Edvinsson, Malone, 1997; Roos, Roos, 1997; Sydler et al., 2013]; and commercial expenditures to assess relational capital [Edvinsson, Malone, 1997, Wu, Tsai, 2005]. This approach does not guarantee accurate results either, since the indicators are calculated using open-source data and do not reflect the actual value of intellectual capital elements: balance sheets and profits-andlosses statements are published in accordance with conservative corporate standards which do not take into account market expectations. An analysis of previously conducted studies (Table 1) reveals that the most commonly used methods for assessing Russian companies' intellectual capital are the VAIC model and the proxy indicators technique based upon it.

As part of the third approach, intellectual capital elements are assessed by surveying company managers using specially designed questionnaires [Sharabati et al., 2010; Suraj, Bontis, 2012]. According to the proponents of this methodology, it allows for conducting an integrated assessment of the overall intellectual capital and its specific elements [St-Pierre, Audet, 2011], so it seems to be best suited for the purposes of our study. We have used a questionnaire designed by a team of experts, participants in an international research project. The questionnaire was tested using Finnish corporate sector data [Inkinen et al., 2014]. The questions and the scales borrowed from the English-language questionnaire were formulated in Russian in line with the standards for cross-cultural studies [Harzing, 2005]. The translation was carried out with the participation of experts, an independent peer review, comparison and adjustment of wording. The translated questionnaire was tested at several companies.

Questions for assessing intellectual capital were borrowed from the work [Inkinen et al., 2014], which in turn was based on other studies: [Kianto, 2008; Yang, Lin, 2009] for relational capital; [Kianto, 2008; Kianto et al., 2010] for structural capital; and [Bontis, 1998; Yang, Lin, 2009] for human capital. Companies' performance was assessed using questions cited in [Delaney, Huselid, 1996], which have proved their theoretical and practical value through numerous empirical tests. These questions are designed to measure the profitability of companies' assets, their sales performance, and the changes in their market share during the year preceding the survey, compared with competitors (Table 3). The answers were ranked using the 5-point Likert scale.

Company size (i.e., the number of employees) and the previous year's financial performance indicators, namely financial leverage and current liquidity ratio, were used as control variables. The debt-to-ownequity ratio (financial leverage) and the current-assets-to-current-liabilities ratio (current liquidity) directly affect companies' financial performance [Chan, 2009; Santidrián, 2010; Sriram, 2008]. Financial stability allows companies to invest in intellectual capital and increase their productivity. Financial data was obtained from the SPARK database. 51 out of the 240 companies in the sample, or $21.2 \%$, did not provide any data for 2014. In subsequent calculations, the control variables were used in logarithmic form. 
Table 3. Questions included in the questionnaire and factor analysis results

\begin{tabular}{|c|c|}
\hline Model's variables and corresponding questions & $\begin{array}{l}\text { Factor loadings, ranging } \\
\text { from } 1 \text { (insignificant) to } \\
5 \text { (high) } \\
\end{array}$ \\
\hline $\begin{array}{l}\text { Company performance: How successful was your company in the previous year compared with other firms } \\
\text { specialising in the same industry, in the following areas? }\end{array}$ & Cronbach's $\alpha=0.851$ \\
\hline Net sales growth & 0.885 \\
\hline Returns on assets* & - \\
\hline Market share & 0.832 \\
\hline Human capital: How true is each of the following statements about your employees' competence? & Cronbach's $\alpha=0.838$ \\
\hline Our employees are highly skilled in their professions & 0.848 \\
\hline Our employees are highly motivated & - \\
\hline Our employees are highly competent & 0.850 \\
\hline Structural capital: How true is each of the following statements about your company's internal structure? & Cronbach's $\alpha=0.830$ \\
\hline We have efficient and adequate information systems in place to support our operations & 0.897 \\
\hline We have tools and mechanisms in place to promote cooperation between our employees & 0.790 \\
\hline Our company's documentation and databases contain a lot of useful knowledge* & - \\
\hline Our documentation and equipment are easily accessible & - \\
\hline $\begin{array}{l}\text { Relational capital: How true is each of the following statements about your company's external and internal } \\
\text { interactions? }\end{array}$ & Cronbach's $\alpha=0.773$ \\
\hline $\begin{array}{l}\text { The company's various departments (e.g. R\&D, Marketing, and Production) understand each other } \\
\text { well }^{*}\end{array}$ & - \\
\hline Our employees frequently work together to accomplish specific objectives & 0.680 \\
\hline Internal interactions in our company are smooth & 0.545 \\
\hline $\begin{array}{l}\text { Our company and its stakeholders (such as consumers, suppliers, and partners) understand each other } \\
\text { well }\end{array}$ & - \\
\hline Our company frequently works together with its stakeholders to accomplish specific objectives & 0.679 \\
\hline $\begin{array}{l}\text { Our company actively cooperates with external stakeholders (such as consumers, suppliers, and } \\
\text { partners) }\end{array}$ & 0.799 \\
\hline
\end{tabular}

\section{Study results}

To test the questions' relevance for measuring the selected variables, a preliminary factor analysis was conducted [Hurley et al., 1997]. Table 3 presents the questionnaire's questions with factor loadings and the scales' internal consistency indicators. Unlike the results of international testing for the questionnaire [Inkinen et al., 2014] whose authors distinguished between external and internal relational capital, we have treated these factors as one and the same. Cronbach's Alpha coefficient for all variables in the model exceeded 0.7 , which is evidence of a high internal consistency and validity of the questions.

Table 4 presents descriptive statistics of latent variables calculated as mean values of answers to relevant questions.

Checking independent variables for multicollinearity produced a negative result: the variance inflation factor (VIF) ranges between 1.173-1.624, so it is quite removed from 3. Preliminary testing also revealed a constant remainder variance and a lack of random errors' heteroscedasticity. The theoretical model was assessed in line with the methodological recommendations in [Anderson, Gerbing, 1988]. First the measurement model was analysed to determine how the data matches the structure of interconnections. Next, the theoretical model based on previous studies (the one presented in the Hypotheses section) was assessed. Following the corroborative factor analysis, some of the answer options were excluded from the questionnaire (marked with ${ }^{*}$ in Table 3), and the analysis's results were applied to test the theoretical model (Figure 1). Since there was no data on two control variables for more than $20 \%$ of companies in the sample, testing was done twice: for all 240 companies using a single control variable (company size), and for a truncated sample, which included 188 companies using three control variables. In both cases the model produced similar results. The results of testing the model for the truncated sample using three control variables are presented below. 
Table 4. Descriptive statistics of variables used in the study

\begin{tabular}{|l|r|r|}
\hline Latent variable & Mean value & Standard deviation \\
\hline Human capital & 4.2 & 0.73 \\
\hline Relational capital & 4.06 & 0.65 \\
\hline Structural capital & 3.95 & 0.84 \\
\hline Company performance & 3.28 & 1.06 \\
\hline Company size (number of employees) & 1024.2 & 4019.7 \\
\hline Financial leverage & 1.49 & 4.06 \\
\hline Current liquidity ratio & 2.52 & 2.95 \\
\hline $\begin{array}{l}\text { Note: correlation is significant at } \mathrm{p}=0.000 \text { (bidirectional). } \\
\text { Source: composed by the authors. }\end{array}$ & & \\
\hline
\end{tabular}

Criteria for testing the model which describes the correlation between the three elements of intellectual capital and company performance are presented in Table 5 (Column 3); they describe the suitability of covariation matrix for the data we have collected. All resulting indicators fall within ranges recommended in the methodological literature.

The testing of the model (Figure 1) revealed that companies' structural and human capital does affect their performance (with B-coefficients of 0.505 and 0.249 , respectively), while relational capital does not. At the same time, all three of these elements have a positive correlation with each other. Among the control variables, only company size had a similar effect, while objective financial performance indicators did not play a comparable role. The latter's impact factors are also shown in Figure 1. On the whole, the model explains $35.4 \%$ of the dependent variable's variation.

\section{Main conclusions}

The study confirmed the hypothesis about structural and human capital affecting manufacturing companies' performance (which explains a quarter of dependent variables' variations), while relational capital does not have such an effect. Structural capital turns out to be more significant than human capital. These conclusions in general match the data obtained over the course of Russian and international studies (see Table 1), with certain important stipulations.

Firstly, the authors of most of the publications on the role intellectual capital plays in business use opensource financial data, in most cases they use the VAIC model to process it. Such an approach does allow one to establish a positive correlation between specific intellectual capital elements and companies' performance [Komnenic, Pokrajcic, 2012; Maditinos et al., 2011], but the indicators built on its basis are not perfect. A survey-based approach, i.e., working with raw data collected using questionnaires, results in a better understanding of the actual state of companies' intellectual capital [St-Pierre, Audet, 2011], and our study is eloquent proof of this.

Secondly, as previous research demonstrated, the contribution of specific elements of intellectual capital to companies' performance may vary depending on the industry [Kianto et al., 2010]. Therefore, the important role of structural capital we have noted may be due to the specific features of our sample, which

\section{Table 5. Results of testing the final model}

\begin{tabular}{|l|l|l|l|}
\hline Designation & Name & \multicolumn{1}{|c|}{$\begin{array}{c}\text { Recommended } \\
\text { value }\end{array}$} & $\begin{array}{c}\text { Values obtained using } \\
\text { the tested model }\end{array}$ \\
\hline Column $\mathbf{3}$ & \multicolumn{1}{c|}{1} & \multicolumn{1}{c|}{3} \\
\hline$\chi^{2} / \mathbf{d f}$ & Ratio of $\chi^{2}$ to the number of degrees of freedom & $\leq 3$ & 1.085 \\
\hline GFI & Goodness-of-fit index & $\geq 0.9$ & 0.975 \\
\hline AGFI & Adjusted goodness-of-fit index & $\geq 0.9(\geq 0.8)$ & 0.952 \\
\hline TLI & Tucker-Lewis index & $\geq 0.95$ & 0.996 \\
\hline CFI & Comparative fit index & $\geq 0.95$ & 0.998 \\
\hline RMSEA & Root Mean Square Error of Approximation & $\begin{array}{l}\leq 0.08 \\
\mathrm{p} \geq 0.05\end{array}$ & $\begin{array}{l}0.024 \\
\mathrm{p}=0.911\end{array}$ \\
\hline Source: compiled by the authors. & & \\
\hline
\end{tabular}




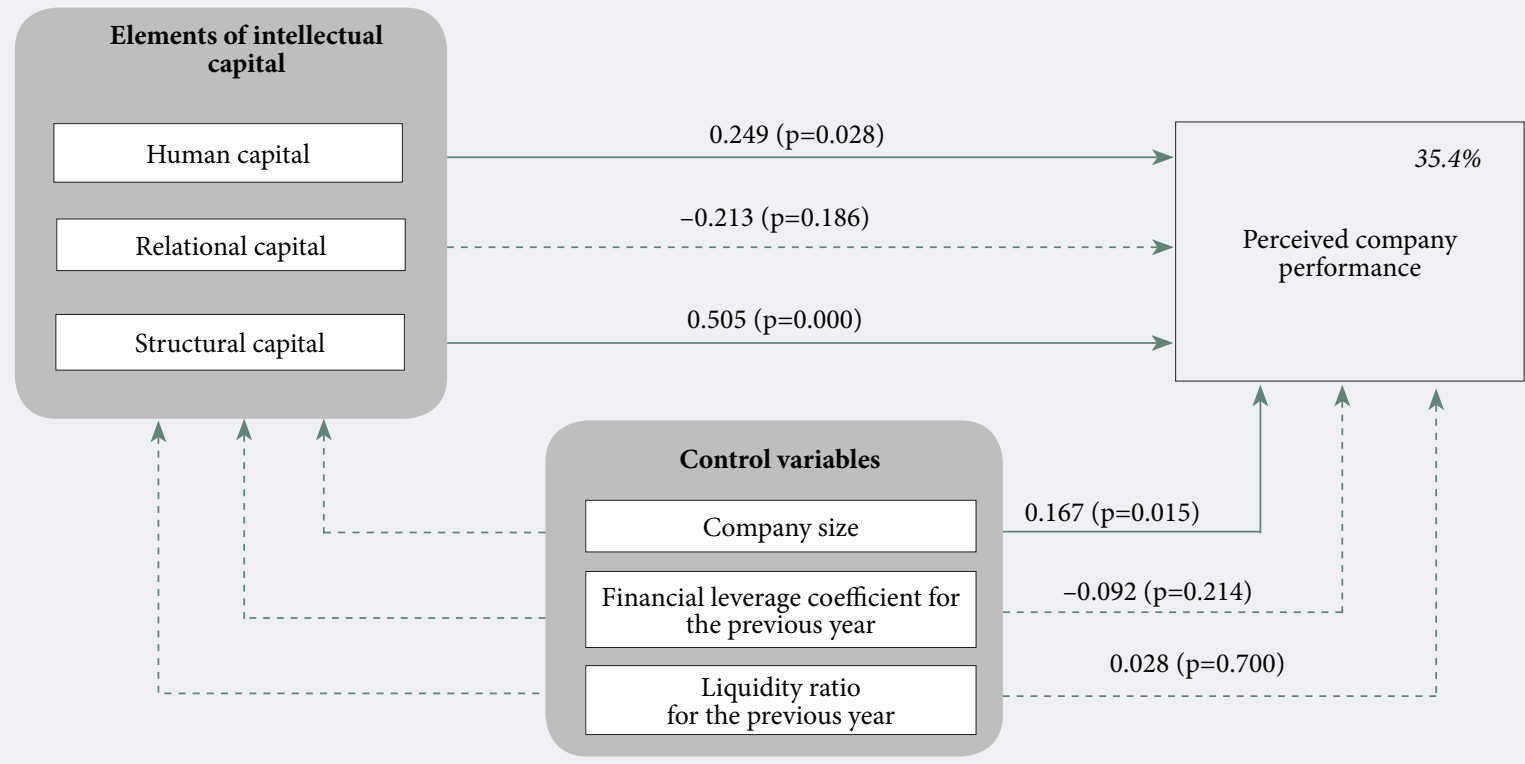

Source: compiled by the authors.

included manufacturing companies. The authors of [Bontis et al., 2000] came to similar conclusions, having proved the exceptional role structural capital plays in the financial performance of companies unrelated to the service sector. At the same time, other studies have demonstrated, using pharmaceutical companies as an example, that human capital can make a no less of a significant impact [Komnenic, Pokrajcic, 2012; Maditinos et al., 2011]. This seems to be quite logical, keeping in mind that personnel is the main source of such companies' innovations and therefore of their success. Another series of studies which have used the telecommunications sector as an example [Garanina, 2010; Suraj, Bontis, 2012] showed that relational capital (a measure of clients' loyalty) may make a critical contribution to such companies' revenues. In turn, [Cabrita, Bontis, 2008] point out that the industry companies specialise in determines the impact that specific elements of intellectual capital make on their performance.

Thirdly, the specifically Russian aspects of doing business matter. The institutional environment and cultural attributes may determine the relative weight of particular elements of intellectual capital in relation to each other. For example, relational capital is especially important to Chinese and Japanese companies [Glisby, Holden, 2003; Michailova, Hutchings, 2006]. We did not analyse the impact of Russian institutional and cultural features on the dynamics of various intellectual capital elements. Indirect evidence of such an impact is provided in a number of knowledge management studies [Andreyeva, Ikhilchik, 2009; May, Stewart, 2013].

The main practical conclusion of our study is that manufacturing companies should concentrate specifically on upgrading and increasing their structural capital, i.e., creating convenient and efficient information systems, designing and applying mechanisms and tools for stepping up cooperation and information exchanges between their staff, cataloguing organisational knowledge, and providing easy access to all of the above facilities to all links of the production chain.

\section{Limitations, and future studies}

Continuing our research in this area involves certain limitations. One of them is due to the nature of data on company performance and intellectual capital elements collected by surveying company managers. As other studies in this field show, the latter has a delayed impact on companies' performance (see, e.g., [Väisänen et al., 2007]). This, combined with specific features of relational capital (a long period required to build it up) allows for suggesting that relational capital's impact on Russian companies has a long-term, inertial character. This hypothesis requires further testing using longitudinal techniques to increase the model's explanatory power (currently intellectual capital elements explain the variation of Russian companies' performance by $35.4 \%$ ). Future studies could combine subjective and objective 
measurements of businesses' performance, which would allow for more accurately measuring intellectual capital's impact on it.

Another possible research area is studying various approaches to and techniques for measuring intellectual capital. For example, a comparative analysis of the heuristic value of indicators based on financial data and on survey results (similar to those presented by us) can be conducted. Finally, the aspects of intellectual capital specific to various industries and sectors of the economy also seem worthy of researchers' attention. One can suggest that in the services sector, human capital would be more important (see, for example, [Kianto et al., 2010]). Applying these arguments to various industries and elaborating them further would help in the acquisition of a more detailed and accurate understanding of intellectual capital's contribution to companies' performance and thus stipulate more efficient management techniques.

The empirical data this study is based upon was collected in the framework of the project No 16.23.1704.2014 "Supporting research by academic personnel of the Graduate School of Management of the St. Petersburg State University". The study was conducted in the scope of the research project No 15-18-30048, sponsored by a grant provided by the Russian Science Foundation.

\section{References}

Anderson J.C., Gerbing D.W. (1988) Structural equation modeling in practice: A review and recommended two-step approach. Psychological Bulletin, vol. 103, no 3, pp. 411-423.

Andreeva T. (2008) Can organisational change be planned and controlled? Evidence from Russian companies. Human Resource Development International, vol. 11, no 2, pp. 119-134.

Andreeva T.E., Ikhil'chik I.A. (2009) Primenimost' modeli sozdaniya znanii SECI v rossiiskom kul'turnom kontekste: teoreticheskii analiz [Applicability of the SECI model of knowledge creation in the Russian cultural context: Theoretical analysis]. Rossiiskii zhurnal menedzhmenta [Russian Management Journal], vol. 7, no 3, pp. 3-20 (in Russian).

Baiburina E.R., Golovko T.V. (2008) Empiricheskoe issledovanie intellektual'noi stoimosti krupnykh rossiiskikh kompanii i faktorov ee rosta [An empirical study of intellectual value of major Russian companies and the factors of its growth]. Korporativnye finansy [Journal of Corporate Finance Research], vol. 2, no 6, pp. 5-19 (in Russian).

Bontis N. (1998) Intellectual capital: An exploratory study that develops measures and models. Management Decision, vol. 36, no 2, pp. 63-76.

Bontis N., Keow W.C.C., Richardson S. (2000) Intellectual capital and business performance in Malaysian industries. Journal of Intellectual Capital, vol. 1, no 1, pp. 85-100.

Bykova A.A., Molodchik M.A. (2011) Vliyanie intellektual'nogo kapitala na rezul'taty deyatel'nosti kompanii [Impact of Intellectual Capital on Organisational Performance]. Vestnik SPbGU: Seriya Menedzhment [Vestnik of Saint Petersburg University. Management Series], no 1, pp. 27-55 (in Russian).

Cabello-Medina C., López-Cabrales A., Valle-Cabrera R. (2011) Leveraging the innovative performance of human capital through HRM and social capital in Spanish firms. International Journal of Human Resource Management, vol. 22 , no 4 , pp. $807-828$.

Cabrita M.D.R., Bontis N. (2008) Intellectual capital and business performance in the Portuguese banking industry. International Journal of Technology Management, vol. 43, no 1, pp. 212-237.

Chan K.H. (2009) Impact of intellectual capital on organisational performance: An empirical study of companies in the Hang Seng Index. The Learning Organisation, vol. 16, no 1, pp. 4-21.

Coombs J.E., Bierly III P.E. (2006) Measuring technological capability and performance. R\&D Management, vol. 36, no 4, pp. 421-437.

Delaney J., Huselid M.A. (1996) The impact of human resource management practices on perceptions of organisational performance. Academy of Management Journal, vol. 39, no 4, pp. 949-969.

Dumay J., Garanina T. (2013) Intellectual capital research: A critical examination of the third stage. Journal of Intellectual Capital, vol. 14, no 1, pp. 10-25.

Edvinsson L., Malone M. (1997) Intellectual capital: Realising your company's true value by finding its hidden brainpower, New York: Harper Collins.

Elenkov D.S. (1998) Can American management concepts work in Russia? A cross-cultural comparative study. California Management Review, vol. 40, no 4, pp. 133-156.

Garanina T.A. (2010) Nematerial'nye aktivy i intellektual'nyi kapital: rol' v sozdanii tsennosti kompanii [Intangible Assets and Intellectual Capital: The Role in Value]. Vestnik SPbGU: Seriya Menedzhment [Vestnik of Saint Petersburg University. Management Series], no 2, pp. 17-44 (in Russian).

Glisby M., Holden N. (2003) Contextual constraints in knowledge management theory: The cultural embeddedness of Nonaka’s knowledge-creating company. Knowledge \& Process Management, vol. 10, no 1, pp. 29-36.

Guthrie J. (2001) The management, measurement and the reporting of intellectual capital. Journal of Intellectual Capital, vol. 2, no 1, pp. 27-41.

Harzing A.-W. (2005) Does the use of English-language questionnaires in cross-national research obscure national differences? International Journal of Cross Cultural Management, vol. 5, no 2, pp. 213-224.

Huang C.-F., Hsueh S.-L. (2007) A study on the relationship between intellectual capital and business performance in the engineering consulting industry: A path analysis. Journal of Civil Engineering and Management, vol. 13, no 4, pp. $265-271$.

Hurley A.E., Scandura T.A., Schriesheim C.A., Brannick M.T., Seers A., Vandeberg R.J., Williams L.J. (1997) Exploratory and confirmatory factor analysis: Guidelines, issues, and alternatives. Journal of Organisational Behavior, vol. 18, pp. 667-683. 
Inkinen H. (2015) Review of empirical research on intellectual capital and firm performance. Journal of Intellectual Capital, vol. 16, no 3, pp. 518-565.

Inkinen H., Kianto A., Vanhala M., Ritala P. (2014) Intellectual capital and performance: Empirical findings from Finnish firms. Paper presented at the International Forum on Knowledge Asset Dynamics (IFKAD), 11-13 June, Matera, Italy.

Jardon C.M., Martos M.S. (2012) Intellectual capital as competitive advantage in emerging clusters in Latin America. Journal of Intellectual Capital, vol. 13, no 4, pp. 462-481.

Kianto A. (2008) Development and validation of a survey instrument for measuring organisational renewal capability. International Journal of Technology Management, vol. 42, no 1-2, pp. 69-88.

Kianto A., Hurmelinna-Laukkanen P., Ritala P. (2010) Intellectual capital in service- and product-oriented companies. Journal of Intellectual Capital, vol. 11, no 3, pp. 305-325.

Kim T., Kim W.G., Park S.S.-S., Lee G., Jee B. (2012) Intellectual capital and business performance: What structural relationships do they have in upper-upscale hotels? International Journal of Tourism Research, vol. 14, no 4, pp. 391-408.

Komnenic B., Pokrajcic D. (2012) Intellectual capital and corporate performance of MNCs in Serbia. Journal of Intellectual Capital, vol. 13, no 1, pp. 106-119.

Maditinos D., Chatzoudes D., Tsairidis C., Theriou G. (2011) The impact of intellectual capital on firms' market value and financial performance. Journal of Intellectual Capital, vol. 12, no 1, pp. 132-151.

May R.C., Stewart W.H. (2013) Building theory with BRICs: Russia's contribution to knowledge sharing theory. Critical Perspectives on International Business, vol. 9, no 1-2, pp. 147-172.

Mention A.-L., Bontis N. (2013) Intellectual capital and performance within the banking sector of Luxembourg and Belgium. Journal of Intellectual Capital, vol. 14, no 2, pp. 286-309.

Michailova S., Hutchings K. (2006) National Cultural Influences on Knowledge Sharing: A Comparison of China and Russia. Journal of Management Studies, vol. 43, no 3, pp. 383-405.

Molnar M.J. (2004) Executive Views on Intangible Assets: Insights from the Accenture (EIU Survey Research Note no 1 "Intangible Assets and Future Value"), London/Dublin: Economist Intelligence Unit/Accenture.

Molodchik M., Shakina E., Barajas A. (2014) Metrics for the elements of intellectual capital in an economy driven by knowledge. Journal of Intellectual Capital, vol. 15, no 2, pp. 206-226.

Molodchik M.A., Nursubina Ya.S. (2012) Innovatsii i intellektual'nyi kapital kompanii: analiz panel'nykh dannykh [Innovation and intellectual capital of the company: The analysis of panel data]. Sovremennye strategii innovatsionnogo razvitiya. Trinadtsatye Drukerovskie chteniya [Modern strategy of innovative development. Thirteenth Druker Readings] (ed. R.M. Nizhegorodtsev), Novocherkassk: Yuzhno-Rossiiskii gosudarstvennyi tekhnicheskii universitet [South-Russian State Technical University], pp. 231-237 (in Russian).

Pulic A. (2000) VAIC - An accounting tool for IC management. International Journal of Technology Management, vol. 20, no 5-8, pp. 702-714.

Reed K.K., Lubatkin M., Srinivasan N. (2006) Proposing and testing an intellectual capital-based view of the firm. Journal of Management Studies, vol. 43, no 4, pp. 867-893.

Roos G., Roos J. (1997) Measuring your company's intellectual performance. Long Range Planning, vol. 30, no 3, pp. 413-426.

Santidrián M.J. (2010) Intellectual capital and value creation in Spanish firms. Journal of Intellectual Capital, vol. 11, no 3, pp. 348-367.

Sharabati A.-A.A., Jawad S.N., Bontis N. (2010) Intellectual capital and business performance in the pharmaceutical sector of Jordan. Management Decision, vol. 48, no 1, pp. 105-131.

Sriram R.S. (2008) Relevance of intangible assets to evaluate financial health. Journal of Intellectual Capital, vol. 9, no 3, pp. 351-366.

St-Pierre J., Audet J. (2011) Intangible assets and performance: Analysis on manufacturing SMEs. Journal of Intellectual Capital, vol. 12, no 2, pp. 202-223.

Subramaniam M., Youndt M.A. (2005) The influence of intellectual capital on the types of innovative capabilities. Academy of Management Journal, vol. 48, no 3, pp. 450-463.

Suraj O.A., Bontis N. (2012) Managing intellectual capital in Nigerian telecommunications companies. Journal of Intellectual Capital, vol. 13, no 2, pp. 262-282.

Sveiby K.E. (1997) The New Organisational Wealth: Managing and Measuring Knowledge Based Assets, San Francisco, CA: Berrett Koehler Publisher.

Sydler R., Haefliger S., Pruksa R. (2014) Measuring intellectual capital with financial figures: Can we predict firm profitability? European Management Journal, vol. 32, no 2, pp. 244-259.

Tomchuk D., Perskii Yu., Sevodina V. (2013) Intellektual'nyi kapital i rentabel'nost' predpriyatiya: kharakteristika i otsenka [The intellectual capital of the company: Characteristics and evaluation]. Resursy, informatsiya, snabzhenie, konkurentsiya [Resources, Information, Procurement, Competition], no 2, pp. 330-334 (in Russian).

Tovstiga G., Tulugurova E. (2007) Intellectual capital practices and performance in Russian enterprises. Journal of Intellectual Capital, vol. 8, no 4, pp. 695-707.

Väisänen J., Kujansivu P., Lönnqvist A. (2007) Effects of Intellectual Capital Investments on Productivity and Profitability. International Journal of Learning and Intellectual Capital, vol. 4, no 4, pp. 377-391.

Volkov D.L., Garanina T.A. (2007) Nematerial'nye aktivy: problemy sostava i otsenivaniya [Intellectual Capital Valuation: Case of Russian Companies]. Vestnik SPbGU: Seriya Menedzhment [Vestnik of Saint Petersburg University. Management Series], no 1, pp. 82-105 (in Russian).

Wu W.Y., Tsai H.J. (2005) Impact of social capital and business operation mode on intellectual capital and knowledge management. International Journal of Technology Management, vol. 3, no 1-2, pp. 147-171.

Yang C., Lin C. (2009) Does intellectual capital mediate the relationship between HRM and organisational performance? Perspective of a healthcare industry in Taiwan. International Journal of Human Resource Management, vol. 20, no 9, pp. 1965-1984. 